\title{
Wildfire Risk Zonation of Sudurpaschim Province, Nepal
}

\author{
Bikram Singh $^{1 *}$, Menuka Maharjan $^{1}$ and Mahendra Singh Thapa ${ }^{2}$
}

\begin{abstract}
Wildfire is one of the major destructive hazards which have significant effect on environment, society, and economy. However, limited studies have been carried out on spatial and temporal distribution of wildfire, especially in developing countries like Nepal. The objective of this study was to assess wildfire risk zonation of Sudurpaschim province of Nepal by applying Remote Sensing and GIS. Sudurpaschim province has been divided into four fire risk zones i.e., high, moderate, low and no risk zone. In Sudurpaschim province, about $30.84 \%$ area falls under high fire risk zone followed by moderate risk $(58.30 \%)$, low risk $(10.13 \%)$ and no risk $(0.72 \%)$. Among five physiographic regions, Siwalik region is more susceptible to fire due to various factors, such as deciduous forest, topography, terrain, etc. From 2012 to 2019, about 44,342 fire incidences were reported in this province. Approximately $88 \%$ wildfire was recorded in spring, the season being dry. Overall, geographically Siwalik region and temporarily spring season should be in high priority for developing and implementing wildfire management activities in Sudurpaschim province.
\end{abstract}

Keywords: Fire risk zonation, remote sensing and GIS, wildfire, Siwalik region

Singh, B., M. Maharjan, and M. S. Thapa. 2020. Wildfire Risk Zonation of Sudurpaschim Province, Nepal. No. 17: page 155 to 173.

DOI: https://doi.org/10.3126/forestry.v17i0.33633

1 Institute of Forestry, Tribhuvan University, Hetauda, Nepal

2 Institute of Forestry, Tribhuvan University, Pokhara, Nepal

* Corresponding author: bikramsingh2051@gmail.com 


\section{Introduction}

Globally, wildfire or forest fire is considered as a hazard for many terrestrial ecosystem resulting in biological and economic loses (Butry et al. 2001), human and wildlife casualties, environmental damages, health hazard including increase in significant amount of Green House Gasses (GHGs) emission accelerating climate change. It plays a vital role in land degradation which causes deforestation and desertification (Hernandez et al. 2006). Wildfire can occur due to natural as well as human activities. It is considered as an important force which damages natural resources. However, its initiation and spread depends upon various factors, i.e., topography, climatic factors, land surface features, and season (Dale et al. 2001).

Annually around $0.4 \%$ of the global land surface is apparently burned which covers 30-46 million $\mathrm{km}^{2}$ (Randerson et al. 2012). Furthermore, over $80 \%$ of the global area burned is grassland and savannahs mostly in Africa and Australia including South Asia and South America, while the remaining 20\% wildfire was documented in forest and shrub-dominated regions (Flannigan et al. 2009). Especially, tropical countries are at high risk of wildfire in dry and hot seasons. According to Global Forest Resources, annually around 19.8 million ha of forests are affected by fire in 118 countries across the world (FAO 2010). Annually 3.73 million ha of forests are affected in India (Satendra and Kaushik 2014). Amazon rainforest fire and California wildfire burned down more than 7 million ha in 2019 and about 404,680 ha in 2018, respectively (Yeung 2020). In the six states of Australia, more than 7.3 million ha of land have already been burned till January, 2020 (Yeung 2020). Directly, 28 people including many volunteer fire fighters (Newey 2020) and almost half billion (480 million) animals have been killed by wildfire in Australia (BBC 2020). According to European Union's Copernicus Atmosphere Monitoring Service, Australia's wildfires have released 400 megatons of carbon dioxide into the atmosphere (Resnick et al. 2020).

Wildfire incidence is increasing globally and Nepal is no exception. Wildfire is very common and the biggest threat to forest covers in Nepal. Wildfire in Nepal mostly occurs due to human activities. Farmers use fire for clearing agricultural land and grazers use fire in pastureland to stimulate sprouting of new nutritious grass (NFFMC 2011). Besides, changes in temperature and precipitation are the reliable evidences of increasing fire occurrences in the country (Negi et al. 2012). Wildfire events are very frequent especially during dry season every year that has significant impact on natural vegetation in Nepal (Parajuli et al. 2015). MODIS sensor recorded 29,844 wildfire occurrences in Nepal from 2003 to 2013 in which 12,269 incidences occurred in forest, grassland, protected area and shrubland (Matin et al. 2017). In 2016, wildfire incidence was remarkably higher (Jenner 2017) resulting loss of about 268,618 ha of forest cover across the country during the months of January-May (Mandal 2019). The same year, the highest density of forest fire was 0.16 with 6.4 hectares burnt area per $\mathrm{km}^{2}$ in the Terai region of Nepal (Bhujel et al. 2017). The monetary term of loss of forest is US\$107,798 (Bhujel et al. 2018). One of the worst 
wildfire caused casualties of 49 people including 13 Nepal Army personnel in Ramechhap district of Nepal in 2009 (Mandal 2019).

Based on historical fire events, Nepal is very vulnerable to wildfire especially in summer season. Previous study shows that $58 \%$ forest fire occurs due to deliberate setting by grazers, poachers, hunters and non-timber forest product (NTFP) collectors; $22 \%$ due to negligence and $20 \%$ by accident in Nepal. More than $80 \%$ fire occurs during spring season, i.e., March and April, while 60\% happens in the month of April only (Mathema 2016). Wildfire assessments proceeding to the disaster events can be the effective mitigation measures for diminishing the potential damages and loss by wildfire (Ghimire et al. 2014). Moreover, wildfire risk mapping considering multiple spatial properties is very critical for prevention of fire, mitigation of negative impacts, and land management (Haas et al. 2013). Understanding the fire risk zonation prediction and its documentation will provide trustworthy guidance to concerned authorities for implementation of effective plan which can minimize disaster to some extent (Chuvieco and Congalton 1989; Verma et al. 2013; Parajuli et al. 2019). However, the institutional capacity to combat the wildfires is very weak in want of systematic and comprehensive record of occurrence and impact of wildfire in Nepal (GoN/MFSC 2002). Assessment of spatial and temporal distribution of wildfire is the first stage for developing the effective wildfire management mechanism in the country. Wildfire risk hazard mapping will delineate the fire prone zone which can guide authorities for applying effective wildfire prevention and suppression tools (Jaafari et al. 2017) in the country.

Globally, Remote Sensing and GIS is the quickest, cheapest, and reliable tools for risk mapping and management of wildfire (Chuvieco and Congalton 1989; Singh and Ajaya 2013). Previous studies suggest that predicted fire potential zones can relate with past fire incidents; thus, fire risk zonation map can be beneficial for future landuse planning (Chhetri and Kayastha 2015). However, limited studies have been carried out on spatial and temporal distribution of wildfire in Nepal. In this regard, Sudurpaschim province is considered as drier region and covers $56.9 \%$ forest area in Nepal (DFRS 2015), thus highly vulnerable to wildfire. Hence, the objective of this study was to assess the wildfire risk zonation of Sudurpaschim province of Nepal by applying Remote Sensing and GIS.

\section{Materials and Methods}

\section{Study Area}

The geographical location of Sudurpaschim province of Nepal is $28.39^{\circ} \mathrm{N}$ to $30.24^{\circ} \mathrm{N}$ and $80.06^{\circ} \mathrm{S}$ to $81.81^{\circ} \mathrm{S}$ (Figure 1). It covers an area of $19789.4 \mathrm{~km}^{2}$. This province has $56.9 \%$ forest of total area having tropical to top Nival climate region. Sal forest is dominant in Terai and Siwalik region while coniferous forest in upper altitude, including alpine scrub. Out of total area of this province, Mid-hills region covers $33.5 \%$ followed by High Mountain (23.7\%), Terai (16.19\%), High Himal (15.1\%), and Siwalik 10.6\%. The province has diverse Land Use Land Cover (LULC) from Terai to 
high mountain, i.e. forest, agriculture, lake, river, built up area, grassland, shrubland and bareland. In Terai region, agriculture land covers $50.13 \%$ area and broadleaved closed forest (33.26\%). Other areas are covered by Bareland, Lake, River, Built up and Shrubland. The northern adjacent region of Terai, i.e. Chure, has more Broadleaved forest cover $(55.24 \%)$ followed by Broadleaved open forest $(24.44 \%)$. Other areas are covered by Agriculture, Bareland, river, Built up area, Grassland and Shrubland. Similar to Terai region, the dominant LULC is agriculture land $(40.96 \%)$ and Broadleaved open forest $(22.56 \%)$ in Mid-hill region. Rest of the areas are covered by Needleleaved closed forest, Broadleaved closed forest, Needleleaved open forest, Shrubland, Grassland, River, Bareland and Built up area. High mountain region has more Needleleaved close forest $(36.68 \%)$ followed by agriculture land $(26.95 \%)$, Needleleaved open forest (14.23\%), Broadleaved open forest $(4.71 \%)$, Broadleaved close forest $(1.76 \%)$, Grassland, Shrubland, River and Snow/glacier. In High Himal region; the dominant LULC are Grassland (39.20\%), Bareland $(25.76 \%)$, and Snow/glacier $(25.03 \%)$. The remaining areas are covered by Needleleaved close forest, Needleleaved open forest, Grassland, Shrubland, Agriculture land, Lake and River.

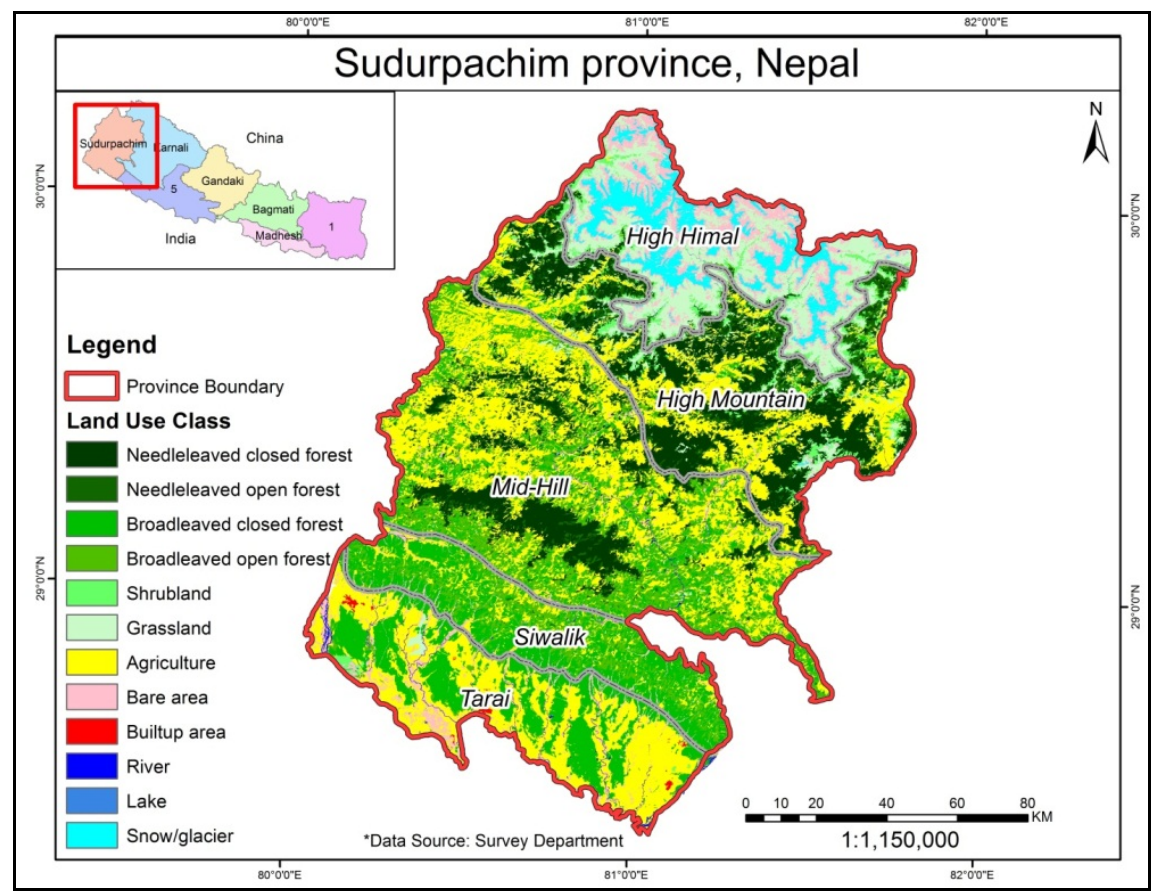

Figure1: Study area location map

\section{Data Used}

Multiple data from 2012 to 2019 were used for mapping forest risk assessment. LULC is major component for fire risk zonation as is considered as most influential factor for wildfire (Ajin et al. 2016a). So LULC map of Department of Survey, 2010 was 
used for this study. Road passing through forest may become risk to wildfire as anthropogenic activities like throwing un-extinguished cigarette butts onto the dry litter, heating bitumen/asphalt for road surfacing, etc., can cause unpredicted fires (Ajin et al. 2016a). Road Map of Survey Department was used for road buffering. Settlement is considered as other important factor for inducing wild fire as neighboring human activities may intentionally or unintentionally set fire to forest (Ajin et al. 2016a). Topography map was used for main settlement location points. Aspect, slope and elevation components are topographic features which play a significant role in fire risk zone analysis (Ajin et al. 2016b; Pandey and Ghosh 2018). SRTM DEM of $30 \mathrm{~m}$ resolution was downloaded from USGS Earth explorer for aspect, slope and elevation data. Visible Infrared Imaging Radiometer Suite (VIIRS) having $375 \mathrm{~m}$ spatial resolution active fire product (2012 to 2019) was downloaded as shape file format for fire sensitivity analysis for each thematic layers.

\section{Data Analysis}

\section{Reclassification and Sensitivity Analysis}

Obtained data from 2012 to 2019 was reclassified on the basis of previous research for all required thematic layers. Then sensitivity of each class of thematic layer was determined based on previous research work by Pandey and Ghosh (2018) and Ajin et al. (2016b) (Table 1) with some modification such as densities of past fire incidents for each class had been considered and weight to each thematic class had been given for weight overlay analysis. For zonation process, different thematic layers were classified by giving weight (Table 1 ) on the basis of fire potentially. The fire risk zone was divided into four classes such as high, moderate, low and no risk area based on vulnerability to fire.

Table 1: Different potential fire risk parameter details

\begin{tabular}{|c|c|c|c|c|}
\hline $\mathbf{S} \mathbf{N}$ & Parameters & Weight & Class & Fire sensitivity \\
\hline \multirow{8}{*}{1} & \multirow{8}{*}{ LULC } & \multirow{8}{*}{60} & Broadleaved forest & High \\
\hline & & & built up & Low \\
\hline & & & Grass land & Moderate \\
\hline & & & Conifer forest & High \\
\hline & & & Shrub & Moderate \\
\hline & & & Water & No Risk \\
\hline & & & Bare land & Low \\
\hline & & & Agriculture & Moderate \\
\hline \multirow[t]{5}{*}{2} & \multirow[t]{5}{*}{ Slope(degree) } & \multirow[t]{5}{*}{15} & $0-10$ & Low \\
\hline & & & $10-20$ & Low \\
\hline & & & $20-30$ & Moderate \\
\hline & & & $30-40$ & Moderate \\
\hline & & & $40-50$ & High \\
\hline
\end{tabular}




\begin{tabular}{|c|c|c|c|c|}
\hline & & & $50-60$ & High \\
\hline & & & $60-75$ & High \\
\hline \multirow{9}{*}{3} & \multirow{9}{*}{ Aspect } & \multirow{9}{*}{10} & Flat & Low \\
\hline & & & $\mathrm{N}$ & Low \\
\hline & & & $\mathrm{NE}$ & Low \\
\hline & & & E & Moderate \\
\hline & & & SE & High \\
\hline & & & $S$ & High \\
\hline & & & SW & High \\
\hline & & & W & Moderate \\
\hline & & & NW & Low \\
\hline \multirow{5}{*}{4} & \multirow{5}{*}{ Distance from road $(\mathrm{m})$} & \multirow{5}{*}{5} & 100 & High \\
\hline & & & 200 & High \\
\hline & & & 300 & Moderate \\
\hline & & & 400 & Moderate \\
\hline & & & $>400$ & No Risk \\
\hline \multirow{5}{*}{5} & \multirow{5}{*}{ Distance from settlement $(\mathrm{m})$} & \multirow{5}{*}{5} & $0-1000$ & High \\
\hline & & & $1000-2000$ & High \\
\hline & & & $2000-3000$ & Moderate \\
\hline & & & $3000-4000$ & Low \\
\hline & & & $>4000$ & No Risk \\
\hline \multirow{5}{*}{6} & \multirow{5}{*}{ Elevation (m) } & \multirow{5}{*}{5} & 500 & Moderate \\
\hline & & & 1000 & Moderate \\
\hline & & & 3000 & Moderate \\
\hline & & & 5000 & Low \\
\hline & & & 6500 & No Risk \\
\hline
\end{tabular}

(Source: Ajin et al., 2016a; Pandey and Ghosh 2018)

Remote sensing and GIS technology is applied for analyzing data. Overall, following work flow was adopted for data analysis (Figure 2). 


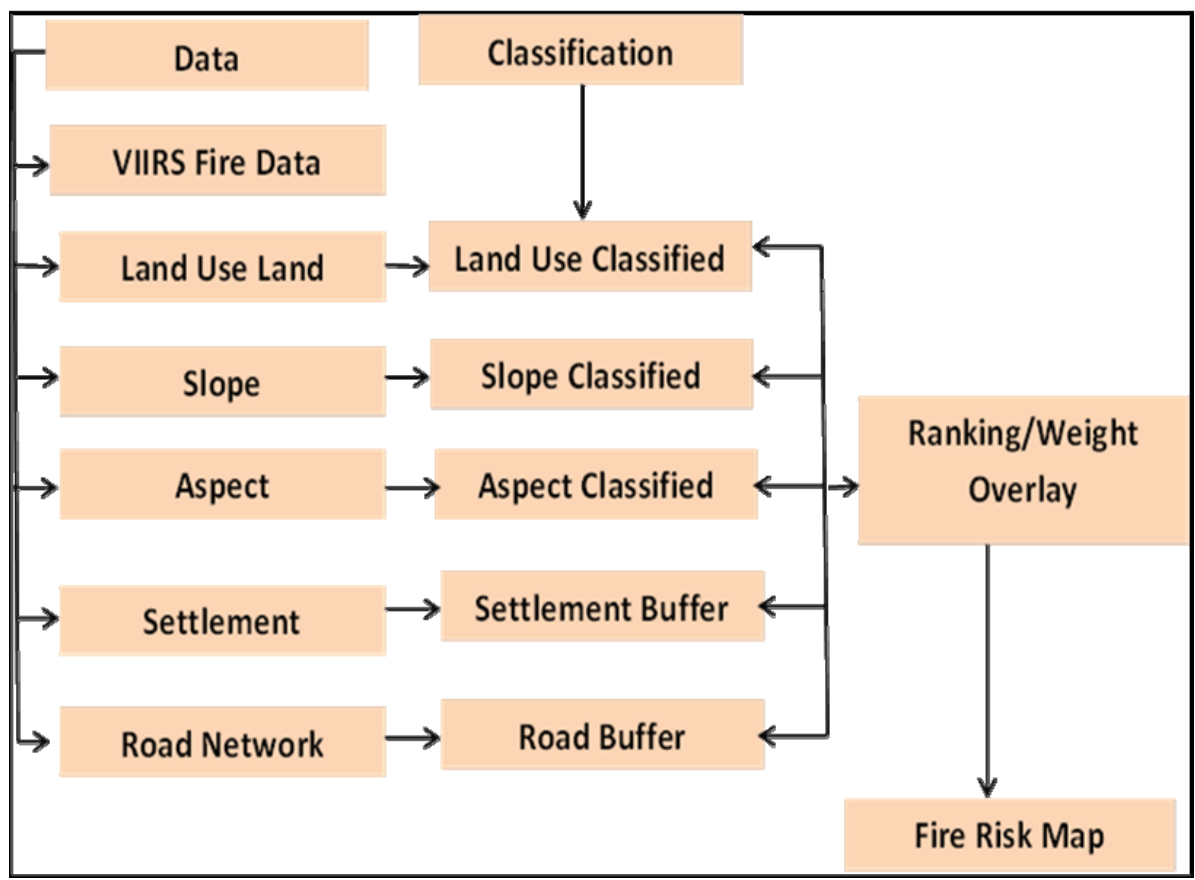

Figure 2: Flow chart of methodology

\section{Results and Discussion}

\section{Results}

\section{Thematic Maps}

All the thematic maps, i.e. LULC (Figure 3A), slope map (Figure 3B), aspect map (Figure 4A), road network buffer map (Figure 4B), settlement buffer map (Fig 5A) and elevation map (Figure 5B) were prepared on the basis of Table 1. Agriculture land is about $29.89 \%$ followed by Broad-leaved closed forest $(27.88 \%)$, needleleaved closed forest $(19.52 \%)$, grassland $(11.48 \%)$, bare area $(6.34 \%)$, river $(4.71 \%)$ and built-up area (0.19\%) in Sudurpaschim Province (Figure 3A).

This province is divided in to seven slope categories, i.e., 0-10, 10-20, 20-30, 30-40, 4050 , and $>60$ (Figure 3B). The slope category 20-30 degree has covered the highest area, i.e. $29.37 \%$ followed by $0-10$ degree class $(24.53 \%), 10-20$ class $(21.55 \%), 30-40$ class $(19.40 \%), 40-50$ class $(4.66 \%), 50-60$ class $(0.32 \%)$ and more than 60 class $(0.003 \%)$. The province covers all aspects almost with equal area, i.e. southwest $(14.17 \%)$ and south $(14.16 \%)$ are aspects with more geographical area coverage followed by west $(13.84 \%)$, southeast $(12.26 \%)$, northwest $(11.14 \%)$, north $(11.43 \%)$, east $(11.17 \%)$, northeast $(10.64 \%)$ and flat land $(1.14 \%)$ (Figure $4 \mathrm{~A})$. Altogether, more than $40 \%$ areas from south, southeast and southwest aspect are highly vulnerable to wildfire. 
The road network of this province has been buffered into five categories, i.e., $100 \mathrm{~m}$, $200 \mathrm{~m}, 300 \mathrm{~m}, 400 \mathrm{~m}$ and $500 \mathrm{~m}$ (Figure 4B). About $6 \%, 5 \%, 5.48 \%$, and $4.56 \%$ of total area falls under fire risk zone from the area nearby road of first category (100 $\mathrm{m})$, second category $(200 \mathrm{~m})$, third category $(300 \mathrm{~m})$ and fourth category $(400 \mathrm{~m})$ respectively. Remaining area falls under no risk of fire in terms of road network. Moreover, the settlement of this province has been buffered into three categories, i.e., first category $(1000 \mathrm{~m})$, second category $(2000 \mathrm{~m})$, third category $(3000 \mathrm{~m})$ and fourth category $(4000 \mathrm{~m})$ (Figure 5A). The first buffer category $(100 \mathrm{~m})$, second buffer category $(200 \mathrm{~m})$, third buffer category $(3000 \mathrm{~m})$, and fourth buffer category $(4000 \mathrm{~m})$ cover $6 \%, 15.85 \%, 17.23 \%, 13.19 \%$ area respectively and fall under fire risk zone from the settlement. Remaining areas fall under no fire risk zone in terms of settlement. Furthermore, the province has been categorized into five elevation classes, i.e., 0-500 $\mathrm{m}, 500-1000 \mathrm{~m}, 1000-3000 \mathrm{~m}, 3000-5000 \mathrm{~m}$ and $>5000 \mathrm{~m}$ (Figure 5B). Among five elevation classes, $1000-3000 \mathrm{~m}$ elevation covers the largest area, i.e., $47.77 \%$ followed by followed by $0-500 \mathrm{~m}(19.75 \%), 3000-5000 \mathrm{~m}(17.45 \%), 500-1000 \mathrm{~m}(11.54 \%)$ and $>5000 \mathrm{~m}(3.46 \%)$.

\begin{tabular}{|l|l|l|}
\hline A Land use land cover map & B & Slope map \\
\hline & & \\
\hline
\end{tabular}

Figure 3: Land use land cover and slope thematic map 


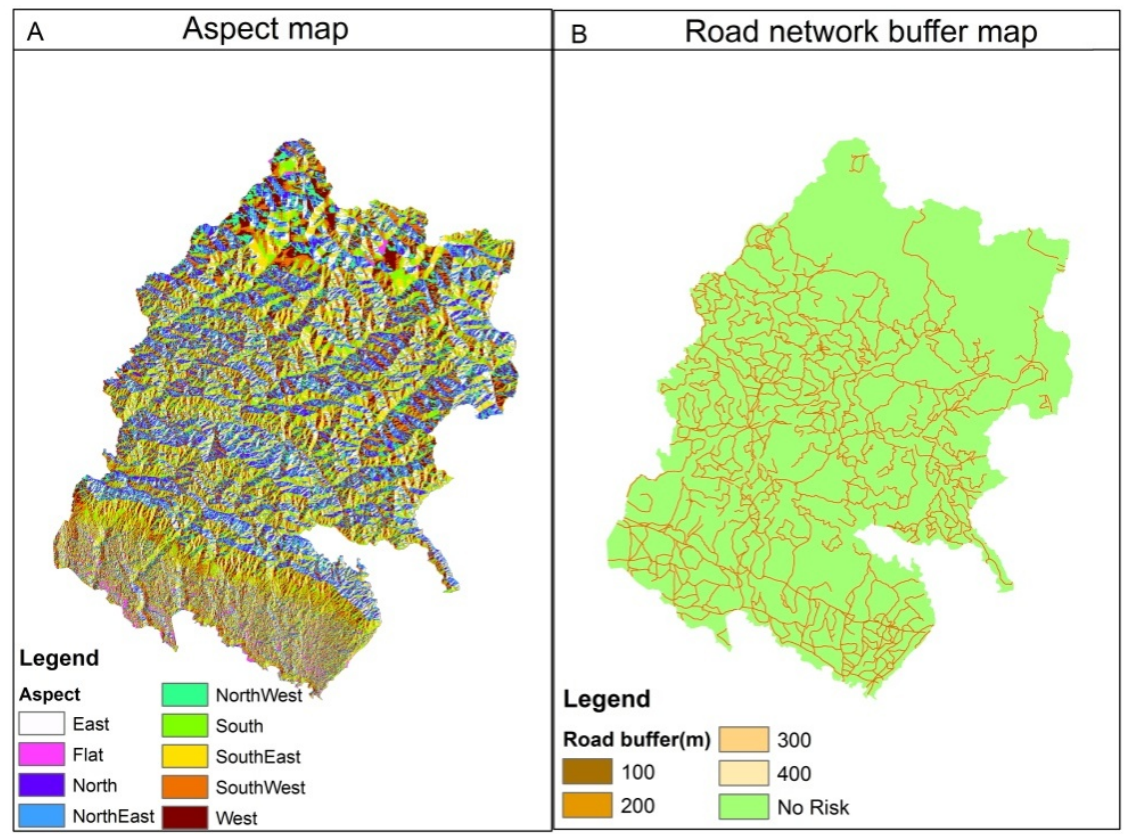

Figure 4: Aspect and road network thematic map

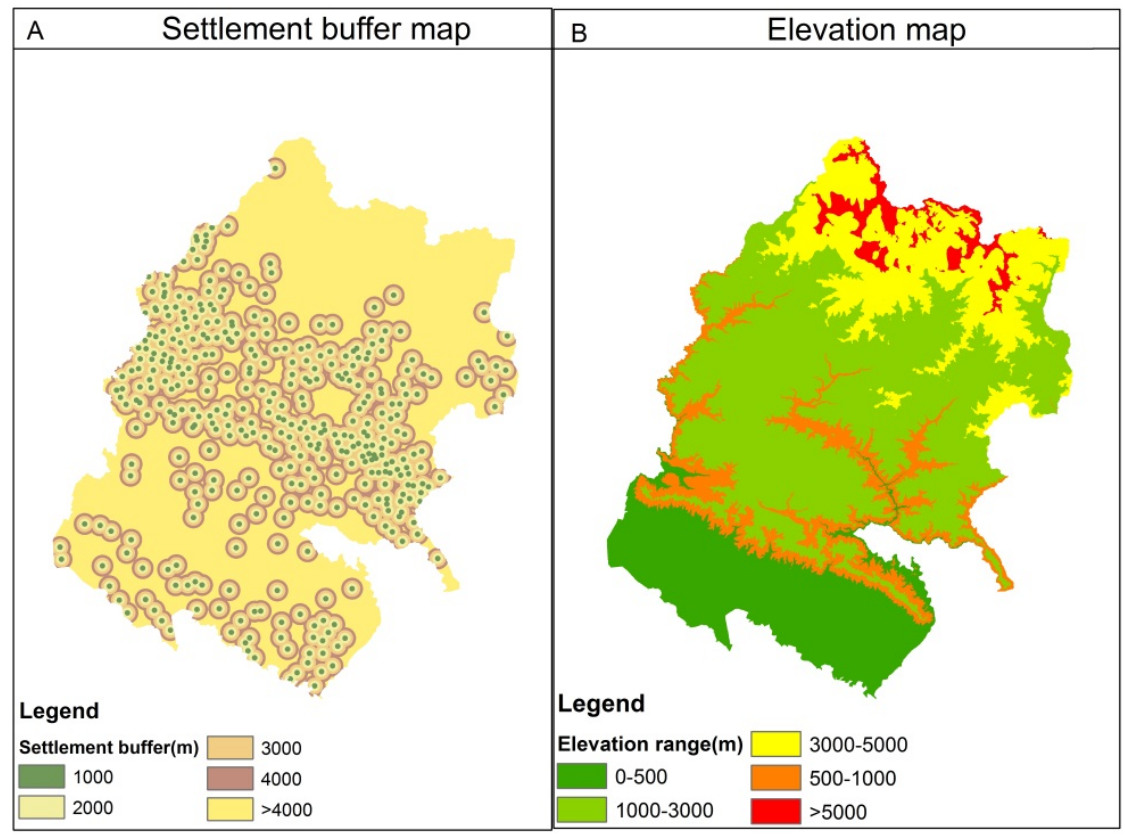

Figure 54: Settlement and elevation thematic map 


\section{Wildfire Risk Layer Zonation of Sudurpaschim Province}

Wildfire risk zonation map was prepared for Sudurpaschim province, Nepal (Figure 6). About $30.85 \%$ of total area of this province falls under high risk zone followed by $58.38 \%$ under moderate, $10.13 \%$ under low risk and $0.72 \%$ under no risk zone. The high fire risk area is spatially distributed in Siwalik region of the province (Figure 6). Furthermore, Terai region, i.e., Kailali and Kanchanpur districts are also fall under high and moderate wildfire risk zone. Suklapahanta National Park of Kanchanpur district (southwest of province) is also under high fire risk zone (Figure 6).

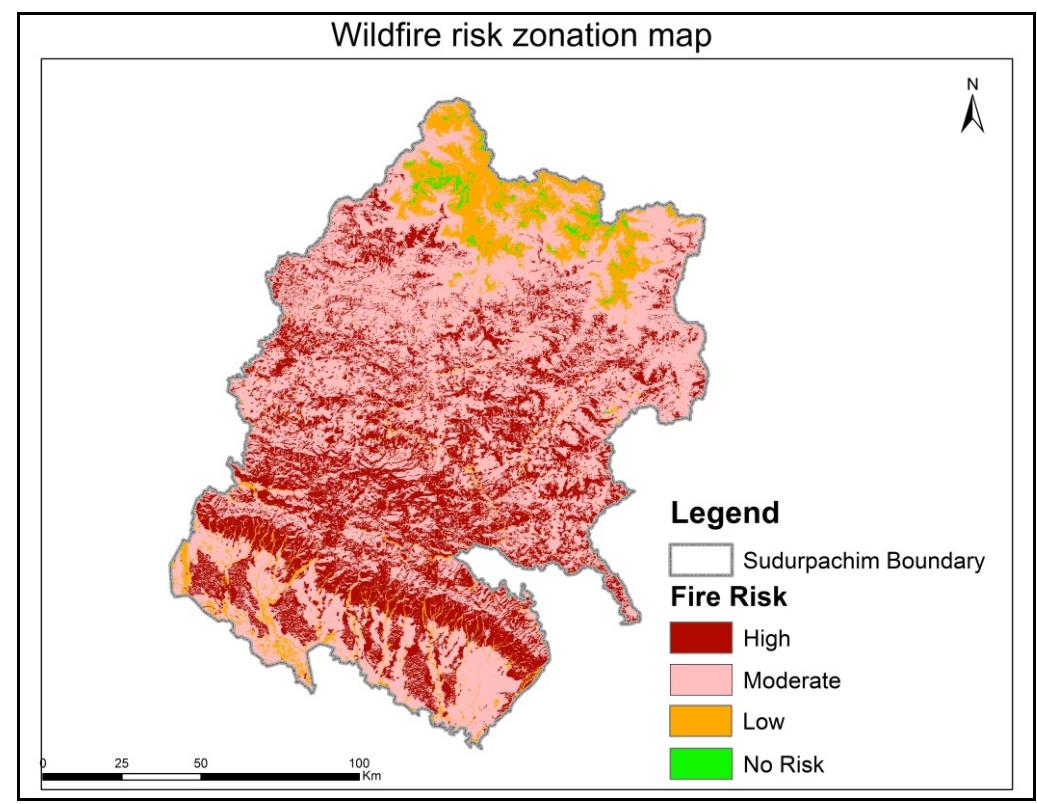

Figure 6: Fire risk zonation map of Sudurpaschim province

\section{Validation for Fire Risk Zonation}

The obtained risk zonation maps were validated by overlaying the past fire occurrence location data and risk layers. Results show that higher numbers of fire incidents occurred with high risk class followed by moderate, low and no risk class. High risk class has larger numbers of fire per square kilometers (4.05) as compared to other classes, i.e., moderate (1.65), low (0.36), and no risk (0.51) (Table 2).

Table 2: Validation Table

\begin{tabular}{|l|l|l|c|}
\hline Fire Risk & Fire Incidents & Area & Density (No. per sq km) \\
\hline High & 24638 & 6081.25 & 4.05 \\
\hline Moderate & 18918 & 11492.3 & 1.65 \\
\hline Low & 713 & 1995.84 & 0.36 \\
\hline No Risk & 73 & 142.59 & 0.51 \\
\hline
\end{tabular}




\section{Wildfire Risk Zonation Based on Physiographic Region}

The spatial distribution of wildfire risk zone was extracted for each physiographic region, i.e., Terai, Siwalik, Mid-hills, High Mountain and High Himal of Sudurpaschim province (Figure 7). Among five physiographic regions, Siwalik region falls under high fire risk zone $(54.9 \%)$ followed by Mid-hills $(40.08 \%)$, Terai (29.22\%), High Mountain (27.18\%) and High Himal (1.48\%) (Figure 7). Only some areas of High Himal and High Mountain, i.e., 4.50\% and $0.02 \%$ respectively, falls under no fire risk zone.

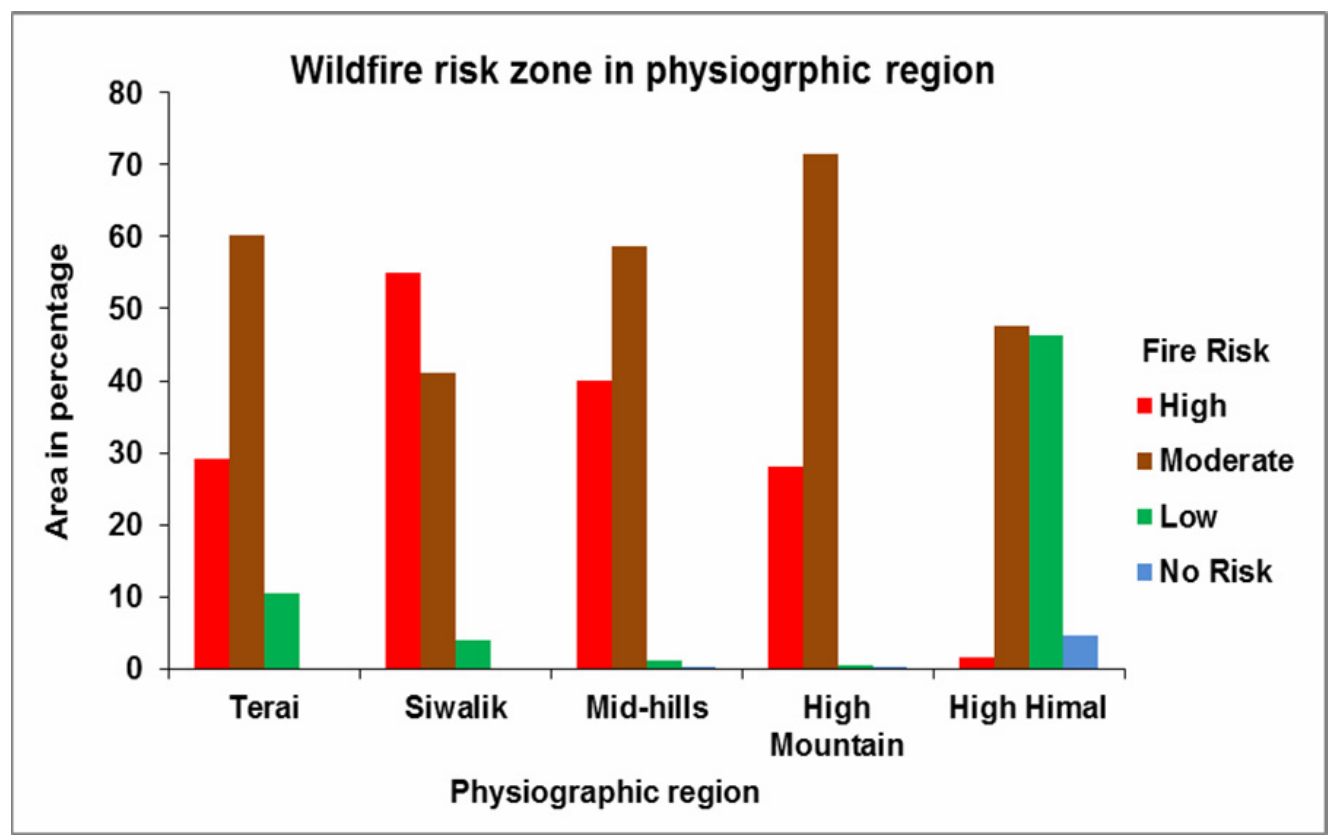

Figure 7: Fire risk area percent in various physiographic regions

\section{Fire Occurrence in Sudurpaschim Province}

Sudurpaschim province had total 44,342 fire incidences between the year 2012 and 2019 (Fig.8). Siwalik region has the highest fire incident density (53.01\%) followed by Terai (21.33\%), Mid-hills (20.28\%), High Mountain (4.20\%) and High Himal (1.18\%). 


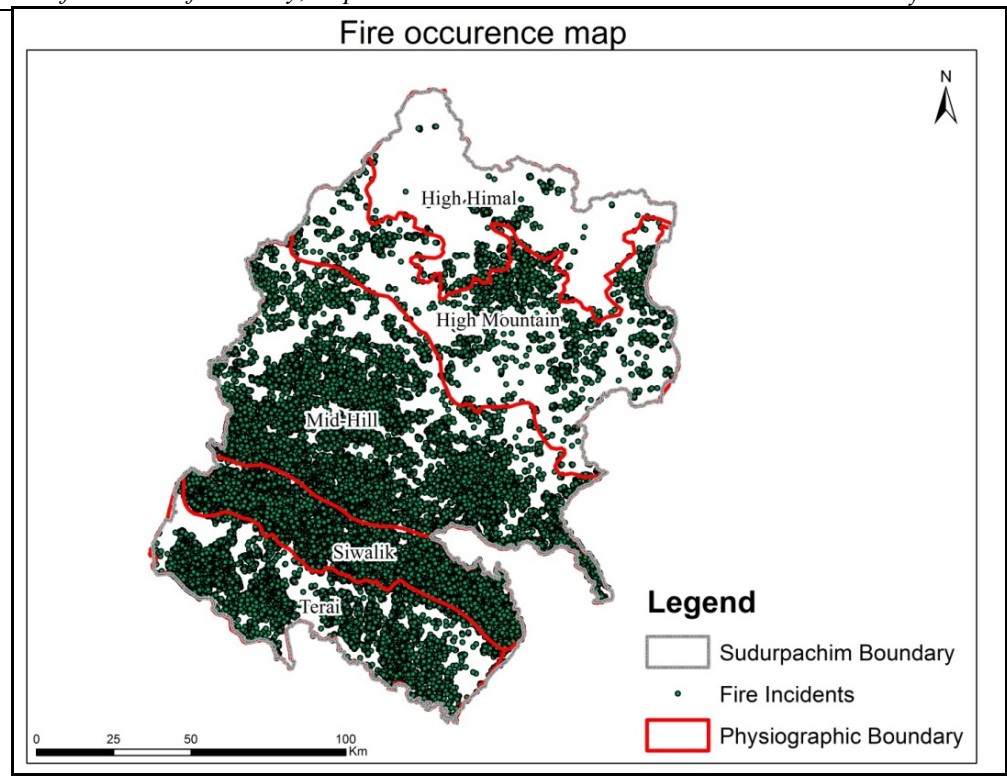

Figure 8: Fire occurrence from 2012 to 2019 in Sudurpaschim province

\section{Seasonality of Fires}

Seasonal fire occurrence was analyzed from 2012 to 2019 in Sudurpaschim province (Fig. 9). Approximately 88\% wildfire recorded in spring season (March-May). Similarly, winter (December-February) was recorded as the second highest, i.e., $5.71 \%$ wildfire incidence season. The lowest fire incidence occurred in autumn season (September-November).

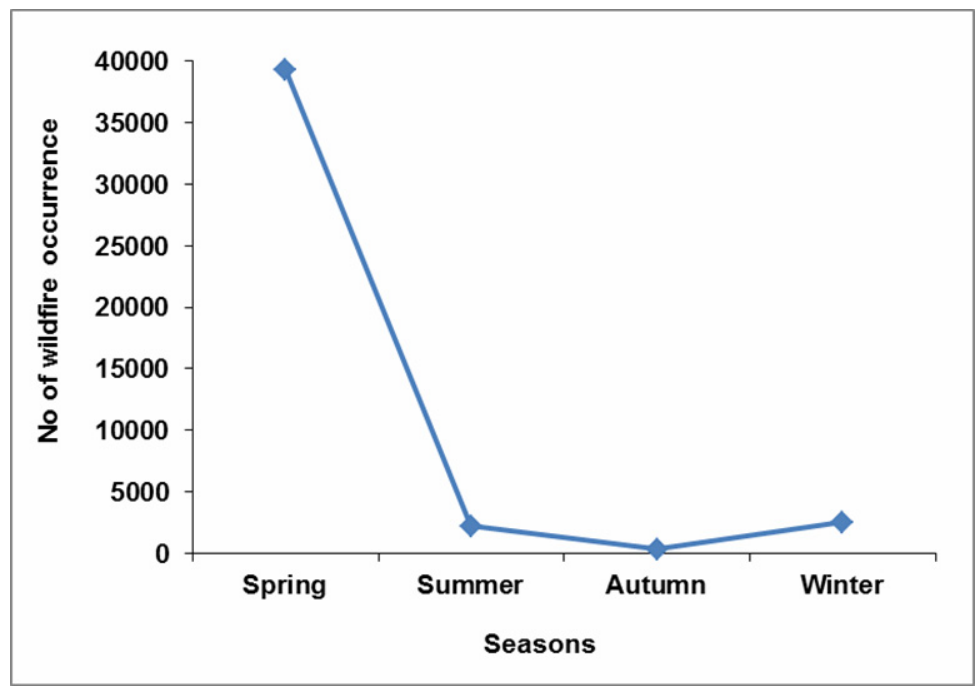

Figure 9: Seasonal wildfire occurrence 


\section{Discussion}

Wildfire is increasing across the world (Bhujel et al. 2017) and various factors, i.e., forest resources, topography, weather conditions are responsible for it (Parisien and Moritz 2009). In Asia, variation in climatic variables, carelessness and unsustainable management of the forests are the main reason behind fire incidence (Streets et al. 2003). In the last decade, there were 138 days of wildfire (Westerling 2016). During 2016, wildfire hazard increased due to high-temperature conditions at the surface in Canada (Petoukhovet al. 2018). About 6,954 wildfires incidents that burned 669,534 acres across the entire state of California were reported (Pimlott 2016). In 2016, around 33664 forest fires were detected in India which covered 52.4 fires per 1000 $\mathrm{km}^{2}$ (MEFC/India 2017). Furthermore, the study done by Kunwar and Kachhawaha (2003) shows that about 2-3\% of the forest area is affected annually by wildfire and on an average over 34,000 ha forest areas are burnt every year in India. In the United States, 3,390 civilian deaths and14,660 fire injuries occurred including damaged of $\$ 10.4$ billion worth property in 2016 (Hylton 2017). Catry et al. (2010) reported that about 127,490 ignitions occurred in Portugal during a five year period. FAO results showed that annually about 4830 ha of forest and rangeland have been destroyed from 2003 to 2007 in Iran (Mohammadi 2009). In Russia, the area affected by fire is 20 $\%$ and forest area has also lost annually (Schaphoff et al. 2016).

Approximately 0.22 million ha of forests, which cover $3.4 \%$ of the whole forest area of Nepal were burnt, destroying $2500 \mathrm{ft}^{3}$ of highly valuable timber and $12500 \mathrm{ft}^{3} \mathrm{fuel}^{-}$ wood in 2016(Bhujel et al. 2018). The loss of timer and fuel wood was equivalent to NRs. 11,750,000 (US\$ 107,798) (Bhujel et al. 2018). Between 2000 and 2013, forest fire caused the largest annual burnt area in the year 2005, 2009 and 2012 with 30,220 hotspots in Nepal (Parajuli et al. 2015). Bhujel et al. (2017) reported that wildfire incidents were 35,374 and the burnt area was 17, 23, and 920 ha from 2000 to 2016 in Nepal. This study reported 44,342 fire incidents between the year 2012 and 2019 in Sudurpaschim province (Figure 8). In western region, Kailali and Kanchanpur districts are severely affected by fire (Matin et al. 2017). This suggests that Sudurpaschim province is highly vulnerable to wildfire. This result is consistent with findings of Parajuli et al. (2015), which indicated that western region falls under high fire risk zone due to low precipitation. Overall, the frequency of forest fire is increasing, significantly harming natural environment and human life in Nepal (Parajuli et al. 2015).

The most significant parameters for the wildfire are land use/land cover types, proximity to roads, aspect, slope and elevation (Sharma et al. 2015). Generally, south aspect receives more sun light making soil dry, which accelerates ignition (Sharma et al. 2015). In Sudurpaschim province, about $14 \%$ of area falls under south and southwest aspect (Figure 4A, which implies that these aspects pose greater fire incidence (Pyne et al. 1996). About $30 \%$ area falls under 20-30 degree slope implying that this category of slope is very prone to fire in Sudurpaschim province (Figure 3B). Locations near road networks are very vulnerable to fire incidence than the places at 
distance due to human interference, i.e. transporting goods, smoking, leakage of oil from tankers, etc. which might result in fire (Pandey and Ghosh 2018; Sharma et al. 2015). About $6 \%$ area falls under fire risk zone due to nearby road $(100 \mathrm{~m})$ in Sudurpaschim province (Figure 4B). Similarly, wild area near settlement is more prone to fire due to anthropogenic activities that can cause accidental fire. In Sudurpaschim province, more settlements are near the forest and within forest, and they increase risk of wildfire (Figure 5A).

Among five physiographic regions, Siwalik region is the most sensitive to fire risk among all other regions (Figure 7 and 8) (Parajuli et al. 2015; Matin et al. 2017; Bhujel et al. 2018) due to various factors, i.e., Sal forest (Verma et al. 2013), sloppy terrain, elevation gradient, etc. that increase the chance of fire ignition (Chuvieco and Salas 1996). Siwalik and Terai regions have more deciduous Sal forests in this province (Figure 3A). A large amount of dry biomass accumulated under deciduous Sal forest (Nhongo et al. 2020) significantly accelerates wildfire. Thus, Siwalik and Terai regions are under high wildfire risk zone (Sharma et al. 2015). Similarly, National Biodiversity Strategy Action Plan (2014-2016) has also emphasized that these regions get higher priority for fire management activity (GoN/MFSC, 2014).

Previous studies have shown that most fire-hit time is February, March and April in South and Southwest forest areas in China (Shu et al. 2001; Thakur and Singh 2014). In India, high wildfires have been reported during March and April due to long dry seasons and droughts (Giriraj et al., 2010). Matin et al. (2017) have shown 89\% wildfires occurrence during pre-monsoon season (March-May) in Nepal. Annually, more than 40,000 ha of forests burn down during March-June in Nepal, resulting in destruction and degradation of forest and biodiversity (Bajracharya 2002). Seasonal analysis of fire incidents shows that spring season (March-May) accounted for around $90 \%$ of fire incidents from 2012 to 2019 in Sudurpaschim province (Figure 9). This result is consistent with the findings of Parajuli et al. (2015) and Bhujel et al. (2017), which show that hot and dry season is conducive to wildfire in the country. Due to short duration and late beginning of monsoon, far-western region suffers more from wildfire than eastern region of Nepal (Kansakar et al. 2004; Parajuli et al. 2015). Burning has significant impact on vegetation and environment due to low moisture content in flammable materials in dry season than in winter season (Bucini and Lambin 2002; Van Wilgen et al 2004). This implies that significant precautions have to be taken during spring season regarding wildfire management in Sudurpaschim province.

Wildfire is taken as one of the destructive hazards which destroy natural resources in short span of time (Sharma et al. 2015). Adequate logistics, infrastructures, financial resources, detailed knowledge on wildfire risk zone including parameters responsible for fire are required for prevention and control management of wildfire (Sharma et al. 2015). Western countries such as Australia, USA and Canada are using wildfire hazard maps for effective preparedness activities to combat wildfires; however such practices are lacking in Nepal (Ghimire et al. 2014). In this regard, 
preparation and distribution of wildfire risk zonation maps can be very effective for the disaster preparedness activities in Nepal (Sharma 2006; Sharma et al. 2015). Thus, this study is an initiative for identifying wildfire high risk zone in Sudurpaschim province which can be helpful for local and federal government to prepare effective wildfire prevention and control mechanism in the province and country.

\section{Conclusion}

Wildfire is influenced by various factors such as land cover, slope, aspect, settlement, road networking and elevation etc. About $30.84 \%\left(6081.25 \mathrm{~km}^{2}\right)$ area of Sudurpaschim province falls under high fire risk zone and followed by moderate risk zone $(58.30 \%)$, low risk zone $(10.13 \%$ and no risk zone $(0.72 \%)$. Among five physiographic regions, Siwalik region is most vulnerable to fire. About 44,342 fire incidents are reported in Sudurpaschim province from 2012 to 2019. Approximately $88 \%$ wildfire in the province was recorded in spring season (March-May) and so it is considered as fire risk season. Thus, findings of this study will be beneficial for authorities and local/federal government for implementing effective wildfire management program in the province. Overall, preparation of wildfire risk zonation map is the first stage for developing wildfire prevention and control mechanism. However, developing country like Nepal has limited infrastructure and financial resources for management of fire hazard. Altogether, geographically Siwalik region and temporally spring season should be in high priority for developing and implementing wildfire management activities in Sudurpaschim province.

\section{Literature Cited}

Ajin, R. S., A. M. Loghin, P. G. Vinod, and M. K. Jacob. 2016a. Forest fire risk zone mapping using RS and GIS techniques: A study in Achankovil Forest Division, Kerala, India. Journal of Earth, Environment and Health Sciences. 2(3), 109-115.

Ajin, R. S., A. M. Loghin, M. K. Jacob, P. G.Vinod, and R. R. Krishnamurthy. 2016b. The risk assessment study of potential forest fire in Idukki Wildlife Sanctuary using RS and GIS techniques. International Journal of Advanced Earth Science and Engineering. 5(1), 308-318.

Bajracharya, K. M. 2002. Forest fire situation in Nepal. International Forest Fire News. 26, 84-86.

BBC.2020. Australia fires: How do we know how many animals have died? Available online at https://www.bbc.com/news/50986293. Accessed date: 27 February, 2020

Bhujel, K. B., R. M. Byanju, and A. P. Gautam. 2018. Wildfire dynamics and its effects on the forest resources and public property in Nepal. Journal of Institute of Science and Technology. 23(1), 61-68.

Bhujel, K. B., R. M. Byanju, and A. P. Gautam. 2017. Wildfire Dynamics in Nepal from 2000-2016.Nep J Environ Sci. 5, 1-8. 
Bucini, G., and E. F. Lambin. 2002. Fire impacts on vegetation in Central Africa: a remote-sensing-based statistical analysis. Applied Geography. 22(1), 27-48.

Butry, D. T., E. D. Mercer, J. P. Prestemon, J. M. Pye, and T. P. Holmes. 2001. What is the price of catastrophic wildfire? Journal of Forestry. 99(11), 9-17.

Catry, F. X., Rego, F. C., Bação, F. L., and Moreira, F. 2010. Modeling and mapping wildfire ignition risk in Portugal. International Journal of Wildland Fire. 18(8), 921-931.

Chhetri, S. K., and P. Kayastha. 2015. Manifestation of an analytic hierarchy process (AHP) model on fire potential zonation mapping in Kathmandu Metropolitan City, Nepal. ISPRS International Journal of Geo-Information. 4(1), 400-417.

Chuvieco, E., and R. G.Congalton. 1989. Application of remote sensing and geographic information systems to forest fire hazard mapping. Remote Sensing of Environment. 29(2), 147-159.

Chuvieco, E., and J. Salas. 1996. Mapping the spatial distribution of forest fire danger using GIS. International Journal of Geographical Information Science. 10(3), 333345 .

Dale, V. H., L. A. Joyce, S. McNulty, R. P. Neilson, M. P. Ayres, M. D. Flannigan, and D. Simberloff. 2001. Climate change and forest disturbances: climate change can affect forests by altering the frequency, intensity, duration, and timing of fire, drought, introduced species, insect and pathogen outbreaks, hurricanes, windstorms, ice storms, or landslides. BioScience. 51(9), 723-734.

DFRS. 2015. State of Nepal's Forests. Forest Resource Assessment (FRA) Nepal, Department of Forest Research and Survey (DFRS). Kathmandu, Nepal.

FAO (Food and Agriculture Organization of the United Nations). 2010. Global forest resources assessment. Main report.FAO Forestry Paper 163.

Flannigan, M. D., M. A. Krawchuk, W. J. de Groot, B. M. Wotton, and L. M. Gowman. 2009. Implications of changing climate for global wildland fire. International Journal of Wildland Fire. 18(5), 483-507.

Giriraj, A., S. Babar, A. Jentsch, S. Sudhakar, and M.S.R. Murthy. 2010. Tracking fires in India using advanced along track scanning radiometer (A) ATSR data. Remote Sensing. 2(2): 591-610.

Ghimire, B., K. Bhujel, and K. Rijal. 2014. Fire hazard zonation of Bardia National Park, Nepal: A disaster preparedness approach. Nep J Environ Sci. 2:27-33.

GoN/MFSC. 2002. Nepal Biodiversity Strategy. Ministry of Forests and Soil Conservation, His Majesty's Government of Nepal.

GoN/MFSC. 2014. Nepal Biodiversity Strategy and Action Plan, 2014-2020. Government of Nepal, Ministry of Forests and Soil Conservation, Kathmandu, Nepal.

Haas, J. R., D. E. Calkin, and M. P. Thompson. 2013. A national approach for integrating wildfire simulation modeling into Wildland Urban Interface risk 
assessments within the United States. Landscape and Urban Planning. 119, 44-53.

Hernandez-Leal, P. A., M. Arbelo, and A. Gonzalez-Calvo. 2006. Fire risk assessment using satellite data. Advances in Space research. 37(4), 741-746.

Hylton, H. 2017. Fire loss in the United States during 2016 report. National Fire Protection Association (NFPA). One-Stop Data Shop 1 Battery march Park Quincy, MA. www.nfpa.org

Jaafari, A., D. M. Gholami, and E. K. Zenner. 2017. A Bayesian modeling of wildfire probability in the Zagros Mountains, Iran. Ecological informatics. 39, 32-44.

Jenner, L. 2017. Forest fire numbers rise in India in 2016, fire and smoke. National Aeronautics and Space Administration (NASA).https://www.nasa.gov/imagefeature/goddard/2016/forest-fire-numbers-rise-in-india-in-2016

Kansakar, S. R., D. M. Hannah, J. Gerrard, and G. Rees. 2004. Spatial pattern in the precipitation regime of Nepal. International Journal of Climatology: $A$ Journal of the Royal Meteorological Society. 24(13), 1645-1659.

Kunwar, P. and T. S. Kachhwaha. 2003. Spatial distribution of area affected by forest fire in Uttaranchal using remote sensing and GIS techniques. Journal of the Indian Society of Remote Sensing. 31(3), 145-148.

Liu, Q., Y. Shan, L. Shu, P. Sun, and S. Du. 2018. Spatial and temporal distribution of forest fire frequency and forest area burnt in Jilin Province, Northeast China. Journal of Forestry Research. 29(5), 1233-1239

Mandal, C.K. 2019. Wildfires single biggest threat to tens of thousands of hectare forest cover. https://kathmandupost.com/national/2019/04/29/wildfires-singlebiggest-threat-to-tens-of-thousands-of-hectare-forest-cover. Accessed date: 25 February, 2020

Matin, M. A., V. S. Chitale, M. S. Murthy, K. Uddin, B. Bajracharya, and S. Pradhan, 2017. Understanding forest fire patterns and risk in Nepal using remote sensing, geographic information system and historical fire data. International Journal of Wildland Fire. 26(4), 276-286.

Mathema, P. 2016. Forest Fire and its management strategies in Nepal. BankoJankari. 23(2):1-2.

Martín, M. P., P. Ceccato, S. Flasse, and I. Downey. 1999. Fire detection and fire growth monitoring using satellite data. In Remote sensing of large wildfires (pp. 101-122). Springer, Berlin, Heidelberg.

MEFC/India. 2017. India state of forest report. Forest Survey of India, Ministry of Environment, Forests and Climate Change (MEFC), Dehradun, India.https://www.fsi.nic.in/forest-report-2017?pgID=forest-report-2017.

Mohammadi, F. 2009. Producing Forest Fire Risk Map, Using Satellite Images and GIS, Paveh, Iran, M.Sc. Thesis report, University of Kurdistan, Kurdistan, Iran. 
Negi, G. C. S., P. K. Samal, J. C. Kuniyal, B. P. Kothyari, R. K. Sharma, and P. P. Dhyani. 2012. Impact of climate change on the western Himalayan mountain ecosystems: An overview. Tropical ecology. 53(3), 345-356.

Newey, S. 2020. Australia is burning - but why are the bushfires so bad and is climate change to blame? https://www.telegraph.co.uk/global-health/climate-andpeople/australia-burning-bushfires-bad/ Accessed date: 27 February, 2020

NFFMC. 2011. Nepal Forest Fire Monitoring Center. Available on online at http://www.nffmc.org/.Accessed date: 15 December, 2019

Nhongo, E. J. S., D. Fontana, and L. Guasselli. 2020. Spatio-temporal patterns of wildfires in the Niassa Reserve-Mozambique, using remote sensing data. bioRxiv.https://www.biorxiv.org/content/10.1101/2020.01.16.908780v1.full. Accessed date: 16 Jan, 2020.

Pandey, K., S. K. Ghosh, and R. Zonation. 2018. Modeling of parameters for forest fire risk zone mapping.42.10.5194/isprs-archives-XLII-5-299-2018. Access date: Nov, 2018.

Parajuli, A., D. B. Chand, B. Rayamajhi, R. Khanal, S. Baral, Y. Malla, and S. Poudel. 2015. Spatial and temporal distribution of forest fires in Nepal. In XIV World Forestry Congress, Durban, South Africa. (pp. 7 11).

https://www.researchgate.net/profile/Shambhu_Paudel/publication/3053 20312_Spatial_and_temporal_distribution_of_forest_fires_in_Nepal/links/5 788467e08ae95560407bed3/Spatial-and-temporal-distribution-of-forest-firesin-Nepal.pdf

Parajuli, A. 2019. Perception of Forest Managers on Fire Management in Two Major Landscapes of Nepal. BiodiversidadeBrasileira-BioBrasil. (1), 60-60.

Parisien, M.A., and M.A. Moritz. 2009. Environmental controls on the distribution of wildfire at multiple spatial scales. Ecological Monographs. 79:127154.https://doi.org/10.1890/07-1289.1

Petoukhov, V., S. Petri, K. Kornhuber ,K. T. honicke, D. Coumou, and H. J. Schellnhuber. 2018. Alberta wildfire 2016: Apt contribution from anomalous planetary wave dynamics. Scientific Reports. 8(1), 1-10.

Pimlott, K. 2016. Wildfire activity statistics.California Department of Forestry and Fire Protection, Governor State of California. https://www.fire.ca.gov/media/10060/2016 redbook final.pdf

Pyne, S. I., P. L. Andrews, and R. D. Laven. 1996. Introduction to wild land fire. Second Edition.John Wiley and Sons.+808pp.

Randerson, J. T., Y. Chen, G. R.Van Der Werf, B. M. Rogers, and D. C. Morton. 2012. Global burned area and biomass burning emissions from small fires. Journal of Geophysical Research:

Biogeosciences. 117(G4).https://doi.org/10.1029/2012JG002128

Resnick, B., U. Irfan, and S. Samuel. 2020. 8 things everyone should know about Australia's wildfire disaster. https://www.vox.com/scienceandhealth/2020/1/8/21055228/australia-fires-map-animals-koalas-wildlife-smokedonate. Accessed date: 27 February, 2020 
Satendra and Kaushik, A.D. 2014. Forest fire disaster management. National Institute of Disaster Management, Ministry of Home Affairs, New

Delhi.www.nidm.gov.in

Schaphoff, S., C. P. Reyer, D. Schepaschenko, D. Gerten, and A. Shvidenko. 2016. Tamm Review: Observed and projected climate change impacts on Russia's forests and its carbon balance. Forest Ecology and Management. 361: 432-44.

Shu, L. and X. Kou. 2001. Study of the pattern of special forest fire behavior by using satellite remote sensing. Fire Safety Science. 10(3):140-144.

Sharma, S. P. 2006. Participatory Forest Fire Management: an Approach. International Forest Fire News. 34, 35-45

Sharma, N.R., Farias P. J. Fernandes, and J.R. Pokharel. 2015. Methodological development for forest fire hazard mapping in Nepal. Brazilian Journal of Cartography. 66:1551-1566

Singh, R. P., and K. Ajay. 2013. Fire risk zone assessment in Chitrakoot area, Satna MP, India. Research Journal of Agriculture and Forestry Sciences. ISSN, 2320, 6063.

Streets, D. G., K. F. Yarber, J. H. Woo, and G. R. Carmichael. 2003. Biomass burning in Asia: Annual and seasonal estimates and atmospheric emissions. Global Biogeochemical Cycle. 17(4): 1099.

Thakur, A. K., and D. Singh. 2014. Forest Fire Risk Zonation Using Geospatial Techniques and Analytic Hierarchy Process. Universal Journal of Environmental Research and Technology.4 (2):82-89.

Van Wilgen, B. W., N. Govender, H. C. Biggs, D. Ntsala, and X. N. Funda 2004. Response of savanna fire regimes to changing fire-management policies in a large African national park. Conservation Biology. 18(6), 1533-1540.

Verma, A. M., D. Singh, S. Dev Sharma, and K. Kamlesh. 2013. Forest fire risk zonation in Raipur Range, Mussoorie Forest Division using: GIS and remote sensing technology. International Journal of Advanced Scientific and Technical Research. 6, 141-150.http://www.rspublication.com/ijst/index.html

Westerling, A. L. 2016. Increasing western US forest wildfire activity: sensitivity to changes in the timing of spring. Philosophical Transactions of the Royal Society B: Biological Sciences. 371(1696), 20150178.

Yeung, J. 2020. Australia's deadly wildfires are showing no signs of stopping. Here's what you need to know. https://edition.cnn.com/2020/01/01/australia/australiafires-explainer-intl-hnk-scli/index.html. Accessed date: 27 February, 2020 